\title{
Effect of Antidiuretic Hormone on Human
}

\section{Small Intestinal Water and Solute Transport}

\author{
Konrad H. Soergel, George E. Whalen, John A. Harris, and \\ JOSEPH E. GEENEN \\ From the Section of Gastroenterology, Department of Medicine, Marquette School of \\ Medicine, Milwaukee County General Hospital, Milwaukee, Wisconsin 53226
}

A в S T R A CT The effect of i.v. Pitressin (ADH) in a dose of $1 \mathrm{U} / \mathrm{hr}$ on permeability characteristics and on absorptive capacity of the normal human small intestine was investigated. The method of continuous intestinal perfusion was employed with polyethylene glycol 4000 as a nonabsorbable marker. Unidirectional flux rates of $\mathrm{Na}$ and $\mathrm{H}_{2} \mathrm{O}$ were calculated from the disapperance of ${ }^{22} \mathrm{Na}$ and of ${ }^{3} \mathrm{HOH}$ from isotonic saline solution within the intestinal lumen. Each study consisted of two successive perfusion periods: one while the subject was hydrated, the other during $\mathrm{ADH}$ infusion or while the subject was dehydrated. Water and sodium absorption from isotonic $\mathrm{NaCl}$ occurred in the hydrated state and was abolished by $\mathrm{ADH}$ as well as by dehydration in the jejunum. In some instances, net gain of water and sodium in the lumen occurred. In the ileum, $\mathrm{ADH}$ and dehydration caused a decrease in water and sodium absorption rate. By contrast, unidirectional flux into the intestinal lumen of water and sodium, as well as dextrose and D-xylose diffusion, remained unchanged by $\mathrm{ADH}$. During perfusions with hypertonic urea solutions the rates of sodium and water entry into the intestine were greatly increased during i.v. $\mathrm{ADH}$ infusion, whereas urea loss from the study segment remained constant. ADH in the dosage used did not affect human intestinal motility. The results suggest that circulating ADH in physiologic concentrations affects the small intestine in one of two ways: increased secretion of

This work appeared in abstract form in 1965 Clin. Res. 13: 261.

Received for publication 31 August 1967 and in revised form 20 November 1967. water and salt into the lumen or direct interference with the active sodium transport mechanism.

\section{INTRODUCTION}

Antidiuretic hormone (vasopressin) has welldefined effects on two types of biological membranes: in minute amounts it increases the water permeability of distal renal tubules and collecting ducts, and in higher concentrations it enhances the permeability of amphibian skin and urinary bladder to water, sodium, and a number of other small solutes such as urea (1). The vasopressor and oxytocic effects of antidiuretic hormone (ADH) appear only with doses some 1000 -fold greater than those required for antidiuresis (2). Indeed, it has been suggested that endogenously produced $\mathrm{ADH}$ has no physiologic effects in addition to its antidiuretic action (3).

A number of reports suggest that small, presumably physiologic, doses of $\mathrm{ADH}$ alter intestinal water and sodium absorption. Injections of 0.01 $\mathrm{U} / \mathrm{kg}$ of body weight caused increased water absorption from isotonic saline in the small intestine of the dog (4) and the rat (5), and the same effect was observed in the rat colon in vitro (6). Levitan and Mauer ( 7$)$, on the other hand, found that $1 \mathrm{U} / \mathrm{hr}$ of $\mathrm{ADH}$ administered intravenously to human subjects resulted in decreased water and sodium absorption from the colon, whereas Green and Matty (8) could not detect any change in sodium absorption by rat ileum and colon and by mouse and toad colon after addition of $\mathrm{ADH}$ to the serosal medium in vitro. In none of these studies was the question evaluated whether en- 
dogenously released $\mathrm{ADH}$ alters intestinal transport and permeability.

The studies to be reported show that circulating $\mathrm{ADH}$ of exogenous, as well as of endogenous origin, regularly decreases the net loss and sometimes causes a net gain of sodium and water during isotonic saline perfusions of the human small intestine. Unidirectional flux of sodium and water into the intestinal lumen as well as bulk flow of water remained essentially unaltered. $\mathrm{ADH}$ had no demonstrable effect on intestinal motility in the doses used.

\section{METHODS}

Healthy men, 21-64 yr old, were studied after a $12 \mathrm{hr}$ fasting period by continuous intestinal perfusion with polyethylene glycol (PEG 4000) as a dilution indicator. Triple lumen perfusion tubes were constructed of polyvinyl tubing, I.D. $1.6-1.8 \mathrm{~mm}$. For isotonic test solutions, the distal tips delineated first a $15 \mathrm{~cm}$ segment for mixing of test solution with fasting intestinal contents and then a $30 \mathrm{~cm}$ intestinal study segment (9). The two distal tips used for aspirations ended in a short piece of perforated $16 \mathrm{~F}$ tubing. A rubber balloon containing about 2 $\mathrm{ml}$ of mercury was tied to the distal end of the perfusion tube, $5 \mathrm{~cm}$ beyond the distal aspiration tip. With hypertonic solutions, perfusion tubes providing a $10 \mathrm{~cm}$ mixing and a $20 \mathrm{~cm}$ study segment were employed because of the rapid adjustment of hypertonic test solutions towards isotonicity during intestinal perfusion (10). Tube position was verified fluoroscopically before and after each perfusion study. For jejunal perfusions, the infusion tip was located about $30 \mathrm{~cm}$ beyond the ligament of Treitz $(100$ $130 \mathrm{~cm}$ from the incisor teeth). For ileal perfusions, the tube length between incisor teeth and infusion tip was $225-290 \mathrm{~cm}$ with no coiling of the tube in the stomach. The test solutions were delivered by a Bowman constant infusion pump at a rate of $9.0-9.4 \mathrm{ml} / \mathrm{min}$; the pump rate through the infusion tip was determined after each study. Samples of intestinal contents were collected by hand aspiration at nearly constant rates of $0.5 \mathrm{ml} / \mathrm{min}$. During hypertonic perfusions, the sampling rate from the proximal aspiration tip was varied according to Fordtran, Rector, Ewton, Soter, and Kinney (10) in order to achieve approximately equal flow rates through the study segment with the different solutions used.

Each perfusion period consisted of a 60 min equilibration period followed by a 30 min collection from the two aspiration tips. The distal aspirations were delayed by the approximate mean transit time of a fluid bolus through the study segment $[2 \mathrm{~cm} / \mathrm{min}$ in jejunum and $3 \mathrm{~cm} / \mathrm{min}$ in ileum (9) ].

$\mathrm{ADH},{ }^{1}$ dissolved in normal saline, was administered at a rate of $1.0 \mathrm{U} / \mathrm{hr}$ by slow i.v. drip; Pitressin from a single production lot was used. Urine and serum osmo-

1 Pitressin, Parke, Davis \& Co., Detroit, Mich. lality and serum $\mathrm{Na}, \mathrm{K}$, and $\mathrm{Cl}$ concentrations were determined during each perfusion period.

Test solutions. All solutions contained PEG 4000, 10 $\mathrm{g} /$ liter. Standard isotonic solution: $140 \mathrm{mM} \mathrm{NaCl} ; 16.7$ mM dextrose; ${ }^{22} \mathrm{NaCl}, 5 \mu \mathrm{c} /$ liter; ${ }^{8} \mathrm{HOH}, 100 \mu \mathrm{c} /$ liter; total osmolality of standard isotonic solution, $289 \pm 2$ $\mathrm{mOsm} / \mathrm{kg}$. Dextrose solution: $65 \mathrm{~mm} \mathrm{NaCl} ; 164 \mathrm{~mm}$ dextrose. D-Xylose solution: $65 \mathrm{~mm} \mathrm{NaCl} ; 164 \mathrm{~mm}$ D-xylose. Hypertonic solutions : $140 \mathrm{~mm} \mathrm{NaCl}$; D-mannitol or urea added to a total osmolality of $800 \mathrm{mOsm} / \mathrm{kg}$.

Analytical procedures. PEG, Na, K, dextrose, mannitol, ${ }^{22} \mathrm{Na}$, and ${ }^{3} \mathrm{H}$ were determined as previously described $(9,11)$. D-Xylose was measured by the method of Roe and Rice (12), chloride by potentiometric titration, (13) and urea by an enzymatic method (14).

Calculations. The calculation of net transport rates from the measured concentration of PEG 4000 and test solutes in the proximal and distal aspirates has been reported (9). The mean concentration of a solute, $S$, in the study segment is given by (11): $\bar{S}=S_{P}-\left[\left(S_{P}-S_{D}\right)\right.$. $0.683]$, where $S_{P}$ and $S_{D}$ are the concentrations of $S$ in the samples obtained from the proximal and distal aspiration tip, respectively. Unidirectional flux rates of water and sodium were calculated from the rate of disappearance of $\mathrm{H}_{3} \mathrm{OH}$ and of ${ }^{22} \mathrm{Na}$ from the perfused study segment, as previously described (11).

Results are reported as mean values $\pm 1 \mathrm{SE}$. The significance of differences in results was tested with the Wilcoxon signed rank test for the difference in means in paired replicates (15).

Study design. All studies started between 8:00 and 10:00 a.m. Individual studies with a given test solution consisted of continuous intestinal perfusion during which a $30 \mathrm{~min}$ aspiration was obtained in the presence and then in the absence of circulating $\mathrm{ADH}$. For the purpose of this study, ADH was considered to be absent from the circulating blood when hydration by rapid i.v. infusions with half-normal saline, $2.5 \%$ and $5 \%$ dextrose in water, had resulted in urine osmolalities of $<250 \mathrm{mOsm} / \mathrm{kg}$, usually $<120 \mathrm{mOsm} / \mathrm{kg}$ throughout the experiment. The standard procedure for evaluating the effect of exogenous ADH on intestinal absorption was as follows. Uninterrupted intestinal perfusion was begun when the subject was hydrated. A 60 min equilibration period was followed by the first $30 \mathrm{~min}$ aspiration period. This period was immediately followed by the start of the i.v. ADH infusion. The second $30 \mathrm{~min}$ aspiration period began $60 \mathrm{~min}$ later during continued intestinal perfusion and i.v. $\mathrm{ADH}$ infusion. Endogenous ADH was assumed to be present when the subjects were dehydrated after 16-20 hr of fasting and when urine osmolality exceeded $800 \mathrm{mOsm} / \mathrm{kg}$. The studies on the effect of the presence or absence of endogenous ADH were conducted on 2 successive days. The perfusion tube was left in place and was taped to the subjects' face overnight. Tube position within the intestine was ascertained fluoroscopically after the lumen leading to the distal aspiration tip was filled with $\mathrm{BaSO}_{4}$ suspension. On each occasion the number of small intestinal loops outlined by the perfusion tube remained unchanged from the beginning of the perfusion on day 1 to the end of the 
study on day 2. With exogenous $A D H$, the i.v. ADH infusion was started at the beginning of the second $60 \mathrm{~min}$ equilibration period of the appropriate test solution for intestinal perfusion. Urine osmolalities exceeded 400 $\mathrm{mOsm} / \mathrm{kg}$ at that time and continued to rise during the aspiration period.

Motility studies. The effect of exogenous $\mathrm{ADH}$ on intestinal motility was evaluated in two ways. (a) Mean transit time of a fluid bolus during continuous perfúsion. Intestinal perfusion with isotonic saline was started in hydrated subjects. After a $60 \mathrm{~min}$ equilibration period, $1 \mathrm{ml}$ of phenol red (PSP) solution was injected through the proximal aspiration tip of the perfusion tube and the PSP concentration of timed samples, obtained from the distal tip located $30 \mathrm{~cm}$ aborad at 2-5-min intervals, was determined. PSP dye-dilution curves were constructed from which the mean transit time through the $30 \mathrm{~cm}$ study segment was calculated (16). Another dye-dilution curve was obtained $1 \mathrm{hr}$ after an i.v. infusion of $\mathrm{ADH}$ $(1.0 \mathrm{U} / \mathrm{hr})$ was started. Only those studies were accepted in which both dye-dilution curves fulfilled the criteria of a single sharp peak followed by a decrease of the concentration vs. time curve which could be fitted to a straight line on a semilog plot (16). An example is shown on Fig. 1. (b) Balloon kymography. A thin-walled rubber balloon attached to a polyvinyl tube ( $1.8 \mathrm{~mm}$ I.D.) was introduced perorally into the proximal jejunum of fasting, hydrated subjects; the tube was taped to the subjects' face. The balloon was inflated with air and connected to a volume recording device (17). After a 30 min base line recording, $A D H$ in a dose of $1 \mathrm{U}$ was injected rapidly through the tubing of a continuous i.v. saline drip, and the recording was continued for another $30 \mathrm{~min}$. Increasing doses of $\mathrm{ADH}$, up to $5 \mathrm{U}$, were then given i.v. with a 30 min recording period after each injection. In separate studies of six hydrated subjects, $\mathrm{ADH}$ was administered by continuous i.v. infusion for $2 \mathrm{hr}$ at a rate of $1 \mathrm{U} / \mathrm{hr}$, and balloon kymographic recordings of jejunal motor activity were obtained during a $30 \mathrm{~min}$ control period and the period of $\mathrm{ADH}$ infusion. Recorded intestinal motor activity tends to diminish during uninterrupted periods of balloon kymography. Therefore, the tracings from the latter studies were compared to 2.5$\mathrm{hr}$ tracings obtained from eight hydrated additional subjects who did not receive $\mathrm{ADH}$. Motility was estimated by the following criteria: (a) tone, expressed as the volume of air within the recording balloon between contractions; $(b)$ the fraction of total recording time during which phasic, small waves occurring at regular rates were present; $(c)$ the frequency and cumulative duration of large waves, defined as lasting $>30 \mathrm{sec}$ and expelling $>5 \mathrm{ml}$ of air from the balloon.

In the studies with single i.v. $\mathrm{ADH}$ injection, results of the initial control period were compared with those obtained during the $10 \mathrm{~min}$ and the entire $30 \mathrm{~min}$ recording period after each $\mathrm{ADH}$ injection. A rise in tone by $>5 \mathrm{ml}$, a $20 \%$ increase in the fraction of time occupied by small waves, or an increase of $33 \%$ in the frequency or duration of large waves were arbitrarily considered to indicate increased jejunal motility. In the studies with continuous i.v. ADH infusion the values for tone and for small and large waves were determined separately for the 0-30 $\mathrm{min}$ and the $30-150 \mathrm{~min}$ period of recording. These results were compared by a signed rank test for unpaired replicates (15) with the corresponding values of the studies in which no ADH had been given.

\section{RESULTS}

Effect of exogenous $A D H$ on net and unidirectional transfer of water and sodium. Nine subjects were perfused in the jejunum and seven in the ileum with the standard isotonic test solution (140 $\mathrm{mm} \mathrm{NaCl}, 16.7 \mathrm{~mm}$ dextrose). During the jejunal studies the mean urine osmolality was $119 \pm 21 \mathrm{mOsm} / \mathrm{kg}$ during hydration and 571 $\pm 53 \mathrm{mOsm} / \mathrm{kg}$ during $\mathrm{ADH}$ infusion; the corresponding values during ileal perfusions were 132 \pm 17 and $512 \pm 43 \mathrm{mOsm} / \mathrm{kg}$. All subjects absorbed water and sodium from the perfused intestinal segment when circulating $\mathrm{ADH}$ was suppressed by i.v. hydration. During ADH infusion, however, water and sodium absorption was decreased or abolished in the jejunum in every instance and during six of seven perfusions in the ileum (Fig. 2A and B). In four of the nine jejunal studies and in two of the seven ileal studies, net gain of water and sodium occurred in the study segment during $\mathrm{ADH}$ administration. Intestinal sodium and chloride transfer rates exhibited parallel changes, whereas the rate of potassium entry into the lumen was not altered by $\mathrm{ADH}$ (Table I). The impression that the striking

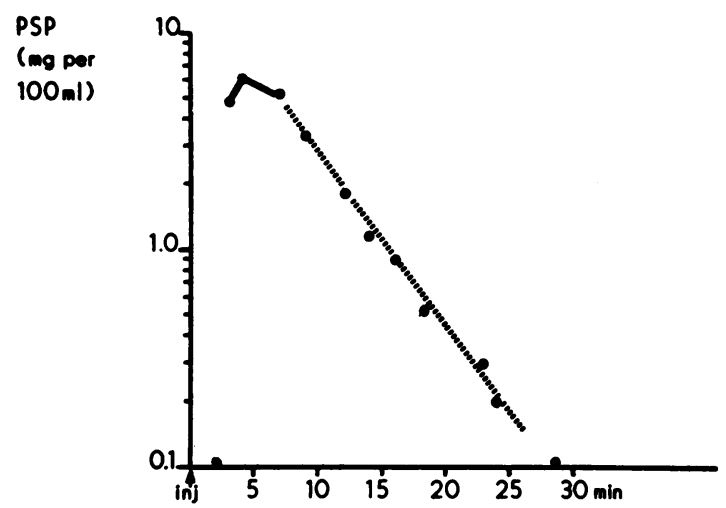

FIGURE 1 Semilogarithmic plot of a representative phenol red (PSP) dye-dilution curve obtained in the jejunum during constant saline perfusion. $5.0 \mathrm{mg}$ of PSP was injected through proximal aspiration tip at $0 \mathrm{~min}$; aspirations were obtained every 2-5 min from the distal aspiration tip. In plotting the graph, corrections were made for the dead space of the tubing. 


\section{JEJUNUM}
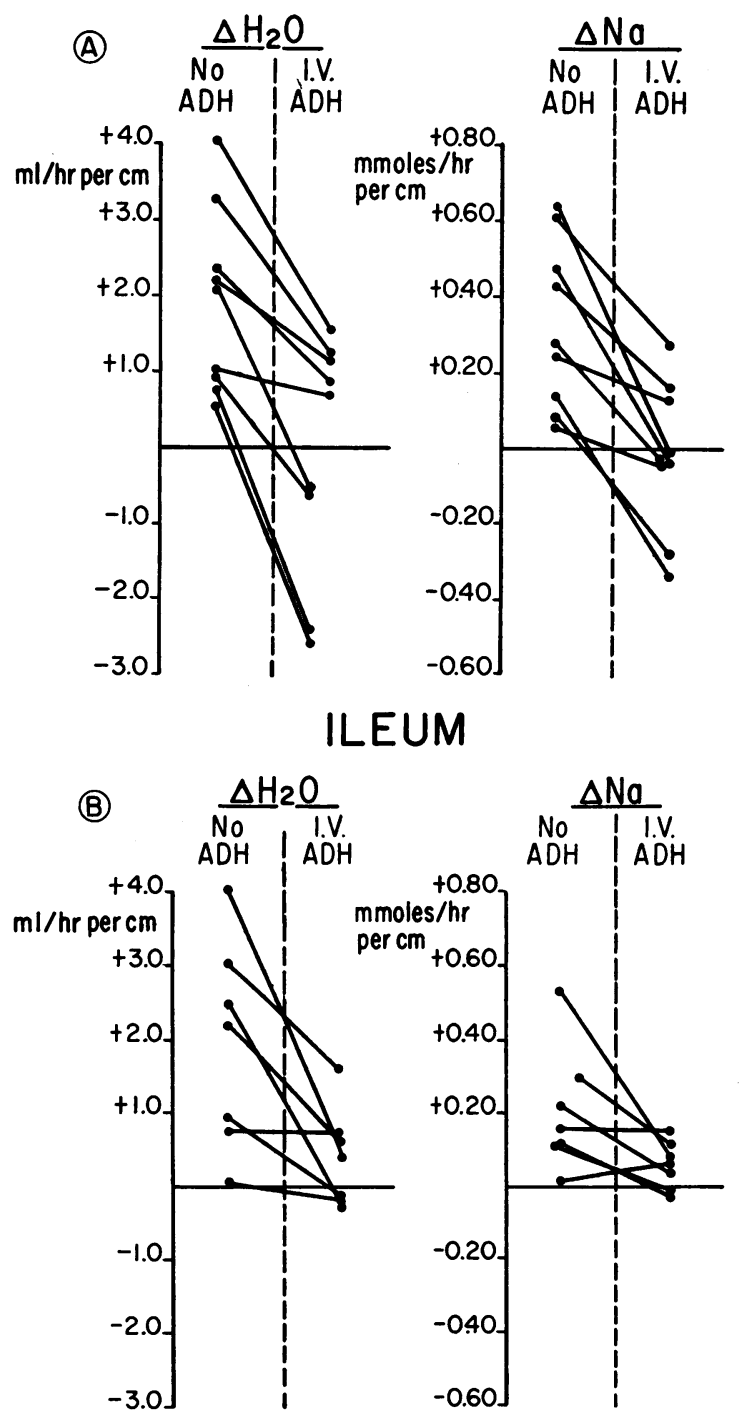

FIgURE $2 \mathrm{~A}$ and $\mathrm{B}$ Effect of i.v. antidiuretic hormone [ADH $(1 \mathrm{U} / \mathrm{hr})]$ on net transfer rates of water and sodium during nine jejunal $(A)$ and seven ileal $(B)$ perfusions with the standard isotonic test solution. Positive sign, absorption; negative sign, gain in intestinal lumen. Data obtained from consecutive perfusion periods are connected by lines.

changes in water and sodium transfer rates found in this experimental situation are due to the presence of circulating ADH is supported by two observations. (a) We have established previously that absorption rates during continuous perfusion with the isotonic test solution are constant for at least $2 \mathrm{hr}$ from the start of the initial sampling period (9). (b) The reversibility of the action of
$\mathrm{ADH}$ on water and sodium transfer rates was demonstrated in five additional jejunal studies in which 30-min intestinal aspirations were obtained before beginning at $60 \mathrm{~min}$ after the start, and beginning at $60 \mathrm{~min}$ after the end of an i.v. $\mathrm{ADH}$ infusion (Fig. 3).

The flow rate of fasting intestinal contents (FIC) was estimated indirectly, based on the linear rate of change of the PEG concentration in the study segment (9). The PEG concentration [PEG], at the infusion tip was obtained by extrapolation from the measured change in [PEG] between proximal and distal aspiration tip. This value will be lower than the [PEG] of the infused test solution when FIC has mixed with the test solution in the mixing segment. The flow rate of FIC can then be calculated (9). In the jejunum it was $1.93 \pm 0.42 \mathrm{ml} / \mathrm{min}(\mathrm{n}=9$, mean $\pm 1 \mathrm{SE})$ without, and $1.57 \pm 0.54 \mathrm{ml} / \mathrm{min}$ with $\mathrm{ADH}$. The corresponding values in the ileum $(n=7)$ were $0.79 \pm 0.30$ and $0.64 \pm 0.27 \mathrm{ml} / \mathrm{min}$. While this method of estimating FIC may not be wholly accurate (9), these results argue against an $\mathrm{ADH}$ induced increase in the flow rate of FIC.

The flux of water and sodium into the intestinal lumen $\left(\phi_{\mathrm{SM}}\right)$ remained nearly unchanged during $\mathrm{ADH}$ infusion, whereas the mean values for flux out of the lumen $\left(\phi_{\mathrm{MS}}\right)$ decreased. The $P$ values for decrease in $\phi_{\mathrm{MS}}$ were between 0.05 and 0.1 , except for $\phi_{\mathrm{MS}}{ }^{\mathrm{H}_{2} \mathrm{O}}$ in the ileum $[P>0.1$ (Table I) ]. The $\mathrm{ADH}$-induced reduction in net absorption of $\mathrm{Na}$ and water was, therefore, associated with decreased flux out of the lumen, but this change did not quite reach statistical significance.

Effect of endogenous $A D H$ on water and sodium absorption. In six subjects, jejunal perfusion with the standard isotonic test solution was performed on 2 successive days: during vigorous hydration with i.v. fluids and after $16-20 \mathrm{hr}$ of dehydration. In four of the subjects perfusion during hydration was followed by perfusion during dehydration; in two subjects this sequence was reversed. Results of these six paired studies, shown in Table II, are similar to those obtained with exogenous $\mathrm{ADH}$. In every subject water, sodium, and chloride absorption rates were lower in the dehydrated state than during hydration, whereas net transfer rate of potassium $(\Delta K)$ remained unaltered.

Additional studies were performed in 10 sub- 
TABLE I

Effect of i.v. ADH (1 U/hr) on Transfer of Water and Sodium from Isotonic NaCl Solution

\begin{tabular}{|c|c|c|c|c|c|c|}
\hline & \multicolumn{3}{|c|}{ Jejunum 9 subjects } & \multicolumn{3}{|c|}{ Ileum 7 subjects } \\
\hline & No ADH & $\mathrm{ADH}$ & $P$ value & No $A D H$ & $\mathrm{ADH}$ & $P$ value \\
\hline$\Delta \mathrm{H}_{2} \mathrm{O}, \mathrm{ml} / \mathrm{hr}$ per $\mathrm{cm}$ & $+2.14 \pm 0.59$ & $-0.06 \pm 0.53$ & $<0.01$ & $+2.28 \pm 0.85$ & $+0.36 \pm 0.25$ & $<0.05$ \\
\hline$\phi_{\mathrm{MS}}{ }^{\mathrm{H}_{2} \mathrm{O}}, \mathrm{ml} / \mathrm{hr}$ per $\mathrm{cm}$ & $11.26 \pm 1.74$ & $9.98 \pm 1.04$ & $>0.05$ & $13.23 \pm 1.35$ & $11.04 \pm 2.64$ & $>0.1$ \\
\hline$\phi_{\mathrm{SM}}{ }^{\mathrm{H}_{2} \mathrm{O}}, \mathrm{ml} / \mathrm{hr}$ per $\mathrm{cm}$ & $9.12 \pm 1.54$ & $10.04 \pm 1.26$ & $>0.5$ & $10.95 \pm 0.96$ & $10.68 \pm 2.44$ & $>0.5$ \\
\hline$\Delta \mathrm{Na}$, mmoles $/ \mathrm{hr}$ per $\mathrm{cm}$ & $+0.33 \pm 0.08$ & $-0.01 \pm 0.07$ & $<0.01$ & $+0.20 \pm 0.06$ & $+0.06 \pm 0.02$ & $=0.05$ \\
\hline$\phi_{\mathbf{M B}}{ }^{\mathrm{Na}}$, mmoles $/ \mathrm{hr}$ per $\mathrm{cm}$ & $0.96 \pm 0.14$ & $0.72 \pm 0.08$ & $>0.05$ & $0.84 \pm 0.12$ & $0.58 \pm 0.14$ & $>0.05$ \\
\hline$\phi \mathrm{SM}^{\mathrm{Na}}$, mmoles $/ \mathrm{hr}$ per $\mathrm{cm}$ & $0.63 \pm 0.08$ & $0.73 \pm 0.11$ & $>0.2$ & $0.64 \pm 0.10$ & $0.52 \pm 0.13$ & $>0.5$ \\
\hline$\Delta \mathrm{K}$, mmoles $/ \mathrm{hr}$ per $\mathrm{cm}$ & $-0.006 \pm 0.006$ & $-0.016 \pm 0.004$ & $>0.2$ & $-0.025 \pm 0.07$ & $-0.021 \pm 0.09$ & $>0.5$ \\
\hline$\Delta \mathrm{Cl}$, mmoles $/ \mathrm{hr}$ per $\mathrm{cm}$ & $+0.37 \pm 0.09$ & $+0.04 \pm 0.08$ & $<0.02$ & $+0.32 \pm 0.08$ & $+0.17 \pm 0.05$ & $<0.05$ \\
\hline
\end{tabular}

Mean values \pm 1 SE.

$\mathrm{ADH}$, antidiuretic hormone (Pitressin); $\Delta$, net transfer rate; positive sign, absorption; negative sign, gain in intestinal lumen; $\phi_{\mathbf{M S}}$, unidirectional flux out of intestinal lumen; $\phi_{\mathbf{S M}}$, flux into lumen.

jects to rule out the possibility that the results of jejunal perfusion studies vary systematically with increasing duration of intestinal intubation. Perfusions with the standard test solution were carried out on 2 successive days after 12-hr fasting periods. The perfusion tube was left in place overnight, and urine osmolality was maintained below $250 \mathrm{mOsm} / \mathrm{kg}$; no $\mathrm{ADH}$ was given. Net absorption rate of water $\left(\Delta \mathrm{H}_{2} \mathrm{O}\right)$ was $+1.35 \pm 0.45$ and $+1.75 \pm 0.37 \mathrm{ml} / \mathrm{hr}$ per $\mathrm{cm}$, on days 1 and 2 ; $\Delta \mathrm{Na}$ was $+0.17 \pm 0.06$ and $+0.23 \pm 0.05$ mmoles/hr per $\mathrm{cm}$, respectively. The changes in absorption rates between day 1 and day 2 were not significant $(P>0.2)$. The possibility remains that the position of the perfusion tube relative to the mucosal area delineated by the two aspiration tips had changed overnight. These results show, however, that the observed changes in water and solute transfer occurred only when the subjects' state of hydration was altered between the 2 successive study days.

Effect of exogenous $A D H$ on dextrose and D-xylose absorption. In view of our observation that $\mathrm{ADH}$ decreases water and sodium absorption from isotonic sodium chloride solution, we investigated whether ADH affects sugar absorption in a similar fashion. No change in dextrose absorption from jejunum nor in $\mathrm{D}$-xylose absorption from jejunum and ileum occurred during the periods of i.v. $\mathrm{ADH}$ administration. With the low

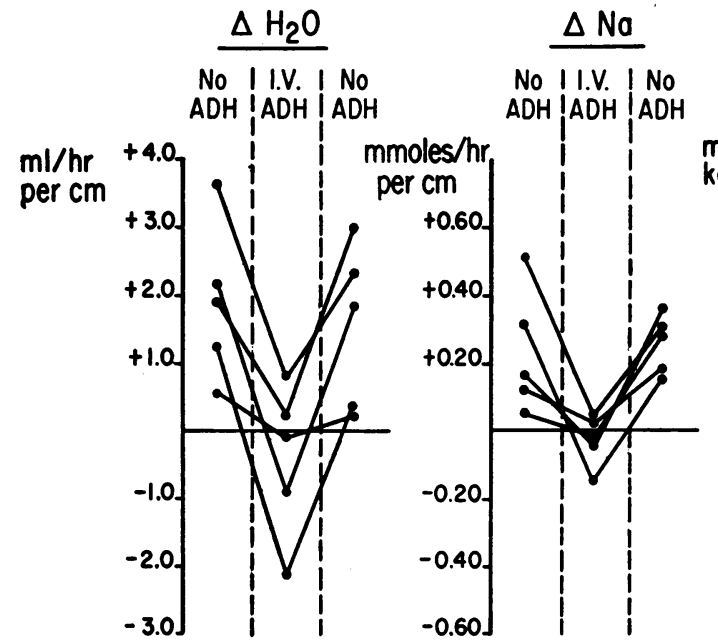

FIGURE 3 Reversibility of the effect of i.v. ADH (1 U/hr) on net transfer rates of water and sodium during five additional jejunal perfusion studies with the standard isotonic test solution. The perfusion lasted for $315 \mathrm{~min}$. The first $30 \mathrm{~min}$ aspiration of intestinal contents occurred at $60-90 \mathrm{~min}$ from the proximal and at 75-105 $\mathrm{min}$ from the distal collection tip. Intravenous $\mathrm{ADH}$ infusion occurred from 105 to 210 min during which the second aspiration was carried out at 165195 min (proximal tip). The third 30 min aspiration started at $270 \mathrm{~min}$ at the proximal tip, that is, $60 \mathrm{~min}$ after the ADH infusion had ended. The subjects were hydrated during the entire study by i.v. infusions of hypotonic $\mathrm{NaCl}$ and of isotonic dextrose solutions. 
TABLE II

Water and Sodium Absorption from Jejunum in the Hydrated and Dehydrated State

\begin{tabular}{lccc}
\hline & Hydrated & Dehydrated & $P$ value \\
\hline$\Delta \mathrm{H}_{2} \mathrm{O}$, ml/hr per $\mathrm{cm}$ & $+3.41 \pm 1.54$ & $-0.78 \pm 1.00$ & $<0.05$ \\
$\Delta \mathrm{Na}$, mmoles $/ \mathrm{hr}$ per $\mathrm{cm}$ & $+0.45 \pm 0.20$ & $-0.03 \pm 0.13$ & $<0.05$ \\
Serum osmolality, $\mathrm{mOsm} / \mathrm{kg}$ & $282 \pm 2$ & $290 \pm 2$ & $<0.05$ \\
Urine osmolality, $\mathrm{mOsm} / \mathrm{kg}$ & $97 \pm 15$ & $895 \pm 70$ & $<0.05$ \\
$\Delta \mathrm{K}$, mmoles $/ \mathrm{hr}$ per $\mathrm{cm}$ & $+0.008 \pm 0.012$ & $-0.001 \pm 0.006$ & $>0.1$ \\
$\Delta \mathrm{Cl}$, mmoles $/ \mathrm{hr}$ per $\mathrm{cm}$ & $+0.49 \pm 0.21$ & $-0.02 \pm 0.15$ & $<0.05$ \\
\hline
\end{tabular}

Data are derived from six subjects. The test solution used was isotonic $\mathrm{NaCl}$.

Mean values $\pm 1 \mathrm{SE}$.

Positive sign, absorption; negative sign, gain in lumen.

lumen sodium concentrations present during these studies net transport of water and sodium were unaffected by $\mathrm{ADH}$ (Table III) ; $\Delta \mathrm{Cl}$ and $\Delta \mathrm{K}$ also remained unchanged.

Hypertonic urea and D-mannitol perfusions: effect of exogenous $A D H$. Hydrated subjects were perfused in random sequence with hypertonic urea and D-mannitol solutions containing $140 \mathrm{~mm}$ $\mathrm{NaCl}$. This perfusion was repeated during i.v. $\mathrm{ADH}$ infusion. The results of 9 jejunal and of 13 ileal studies are shown on Tables IV and V. Addition of water to lumen and loss of solute from the intestinal lumen during urea perfusions resulted in a rapid fall of the osmolality of the infused test solutions. The rate of decrease in total solute concentration was slower in ileum than in jejunum as shown by the larger osmotic gradient (i.e., the difference between mean lumen osmolality and serum osmolality) present in the distal than in the proximal small intestine. In agreement with previous reports $(10,11)$ the intestinal mucosa proved to be impermeable to D-mannitol. The effective osmotic pressure exerted by this solute on the mucosal membrane equals, therefore, its contribution to the measured osmolality of intestinal contents. During D-mannitol perfusions, $\mathrm{ADH}$ administration caused no alterations in the transfer rates of water and solutes across the ileal mucosa, whereas in the jejunum the rate of water entry per unit osmotic gradient $\left(\Delta \mathrm{H}_{2} \mathrm{O}\right.$ per osmotic gradient), as well as the rate of sodium entry, increased by about $25 \%$. During hypertonic urea perfusions, however, striking changes in water and sodium transfer rates were observed when $\mathrm{ADH}$ was infused intravenously. Entry of water into the study segment was greatly

TABLE III

Effect of Intravenous ADH $(1 \mathrm{U} / \mathrm{hr})$ on Absorption of $164 \mathrm{mM}$ Dextrose and of $164 \mathrm{mM}$ D-Xylose in NaCl $65 \mathrm{mM}$

\begin{tabular}{|c|c|c|c|c|c|c|c|}
\hline & & \multirow[b]{2}{*}{$\Delta$ Monosaccharide } & \multirow[b]{2}{*}{$\Delta \mathrm{H}_{2} \mathrm{O}$} & \multirow[b]{2}{*}{$\Delta \mathrm{Na}$} & \multicolumn{2}{|c|}{ Mean lumen concn } & \multirow[b]{2}{*}{ Urine osmolality } \\
\hline & & & & & Sugar & $\mathrm{Na}$ & \\
\hline $\begin{array}{l}\text { Jejunum, dextrose } \\
7 \text { subjects }\end{array}$ & $\begin{array}{l}\text { No } \mathrm{ADH} \\
\mathrm{ADH} \\
P \text { value }\end{array}$ & $\begin{array}{c}\text { mmoles } / \mathrm{hr} \text { per } \mathrm{cm} \\
+1.00 \pm 0.13 \\
+1.10 \pm 0.16 \\
>0.2\end{array}$ & $\begin{array}{c}\mathrm{ml} / \mathrm{hr} \text { per cm } \\
+3.96 \pm 1.17 \\
+4.50 \pm 1.44 \\
>0.2\end{array}$ & $\begin{array}{c}\text { mmoles } / \mathrm{hr} \text { per cm } \\
+0.10+0.08 \\
+0.15 \pm 0.12 \\
>0.2\end{array}$ & $\begin{array}{c}\text { mmoles } / l \\
93 \pm 9 \\
91 \pm 6 \\
>0.2\end{array}$ & $\begin{array}{l}\text { iter } \\
85 \pm 4 \\
83 \pm 3 \\
>0.2\end{array}$ & $\begin{array}{c}m O s m / k g \\
72 \pm 15 \\
434 \pm 23 \\
=0.02\end{array}$ \\
\hline $\begin{array}{l}\text { Jejunum, D-xylose, } \\
8 \text { subjects }\end{array}$ & $\begin{array}{l}\text { No } \mathrm{ADH} \\
\mathrm{ADH} \\
P \text { value }\end{array}$ & $\begin{array}{c}+0.38 \pm 0.08 \\
+0.39 \pm 0.11 \\
>0.2\end{array}$ & $\begin{array}{c}+0.03 \pm 0.77 \\
-0.13 \pm 0.56 \\
>0.2\end{array}$ & $\begin{array}{c}-0.14 \pm 0.10 \\
-0.15 \pm 0.05 \\
>0.2\end{array}$ & $\begin{array}{c}110 \pm 5 \\
106 \pm 6 \\
>0.2\end{array}$ & $\begin{array}{c}83 \pm 2 \\
82 \pm 2 \\
>0.2\end{array}$ & $\begin{array}{c}80 \pm 12 \\
436 \pm 23 \\
<0.02\end{array}$ \\
\hline $\begin{array}{l}\text { Ileum, D-xylose, } \\
7 \text { subjects }\end{array}$ & $\begin{array}{l}\text { No ADH } \\
\text { ADH } \\
P \text { value }\end{array}$ & $\begin{array}{c}+0.12 \pm 0.03 \\
+0.19 \pm 0.09 \\
>0.2\end{array}$ & $\begin{array}{c}-0.02 \pm 0.40 \\
+0.87 \pm 0.33 \\
>0.05\end{array}$ & $\begin{array}{c}+0.02 \pm 0.04 \\
+0.09 \pm 0.06 \\
>0.1\end{array}$ & $\begin{array}{c}143 \pm 4 \\
140 \pm 5 \\
>0.2\end{array}$ & $\begin{array}{c}65 \pm 3 \\
64 \pm 2 \\
>0.2\end{array}$ & $\begin{array}{c}116 \pm 22 \\
492 \pm 33 \\
\quad=0.02\end{array}$ \\
\hline
\end{tabular}

Mean values $\pm 1 \mathrm{SE}$.

Positive sign, absorption, negative sign, gain in lumen. 
TABLE IV

Effect of i.v. ADH (1 U/hr) on Jejunal Water and Solute Transfer during Hypertonic Perfusions

\begin{tabular}{|c|c|c|c|c|c|c|}
\hline & \multicolumn{3}{|c|}{ Urea } & \multicolumn{3}{|c|}{ D-Mannitol } \\
\hline & No ADH & $\mathrm{ADH}$ & $P$ value & No ADH & $\mathrm{ADH}$ & $P$ value \\
\hline$\Delta \mathrm{H}_{2} \mathrm{O}, \mathrm{ml} / \mathrm{hr}$ per cm & $-0.67 \pm 0.11$ & $-3.84 \pm 0.83$ & $<0.001$ & $-8.19 \pm 1.16$ & $-8.96 \pm 1.20$ & $>0.2$ \\
\hline $\begin{array}{l}\text { Osmotic gradient, } \\
\mathrm{mOsm} / \mathrm{kg}^{*}\end{array}$ & $130 \pm 9$ & $99 \pm 10$ & $<0.05$ & $150 \pm 8$ & $123 \pm 8$ & $=0.05$ \\
\hline $\begin{array}{l}\Delta \mathrm{H}_{2} \mathrm{O} \text { per osmotic } \\
\text { gradient }\end{array}$ & $0.005 \pm 0.001$ & $0.039 \pm 0.003$ & $<0.01$ & $0.058 \pm 0.009$ & $0.073 \pm 0.010$ & $=0.05$ \\
\hline$\Delta \mathrm{Na}$, mmoles $/ \mathrm{hr}$ per $\mathrm{cm}$ & $+0.11 \pm 0.04$ & $-0.34 \pm 0.10$ & $<0.01$ & $-0.37 \pm 0.08$ & $-0.45 \pm 0.11$ & $=0.05$ \\
\hline$\Delta \mathrm{K}$, mmoles $/ \mathrm{hr}$ per $\mathrm{cm}$ & $-0.021 \pm 0.004$ & $-0.027 \pm 0.004$ & $>0.1$ & $-0.023 \pm 0.04$ & $-0.028 \pm 0.05$ & $>0.2$ \\
\hline $\begin{array}{l}\text { Mean Na concn, } \\
m E q / \text { liter }\end{array}$ & $114 \pm 2$ & $110 \pm 2$ & $<0.02$ & $97 \pm 3$ & $95 \pm 2$ & $>0.2$ \\
\hline $\begin{array}{l}\Delta \text { urea or mannitol, } \\
\text { mmoles } / \mathrm{hr} \text { per } \mathrm{cm}\end{array}$ & $+3.01 \pm 0.29$ & $+2.73 \pm 0.31$ & $>0.2$ & $+0.023 \pm 0.031 t$ & $+0.031 \pm 0.032 \ddagger$ & $>0.2$ \\
\hline $\begin{array}{l}\text { Mean urea concn, } \\
\text { mmoles/liter }\end{array}$ & $175 \pm 8$ & $170 \pm 8$ & $>0.2$ & - & - & - \\
\hline $\begin{array}{l}\text { Urine osmolality, } \\
\quad \mathrm{mOsm} / \mathrm{kg}\end{array}$ & $108 \pm 9$ & $506 \pm 37$ & $<0.01$ & $132 \pm 10$ & $572 \pm 39$ & $<0.01$ \\
\hline$\Delta \mathrm{mOsm}, \mathrm{mOsm} / \mathrm{hr}$ per $\mathrm{cm}$ & $+3.29 \pm 0.27$ & $+2.03 \pm 0.24$ & $<0.02$ & $-0.73 \pm 0.11$ & $-0.70 \pm 0.14$ & $>0.05$ \\
\hline $\begin{array}{l}\text { Calculated } \Delta \text { mOsm§, } \\
m O s m / h r \text { per cm }\end{array}$ & $+3.17 \pm 0.31$ & $+2.05 \pm 0.28$ & $<0.02$ & $-0.70 \pm 0.16$ & $-0.85 \pm_{\mathrm{i}}^{\prime} 0.21$ & $>0.05$ \\
\hline
\end{tabular}

Data are derived from nine subjects.

Mean values $\pm 1 \mathrm{SE}$.

Positive sign, loss from lumen; negative sign, gain in lumen.

* Difference between serum and mean lumen osmolality.

‡ Values not significantly different from zero.

$\S$ Calculated $\Delta \mathrm{mOsm}=[(\Delta \mathrm{Na}+\Delta \mathrm{K}) \cdot 1.843+\Delta$ urea or mannitol $] .1 .843$ is the osmotic coefficient for $\mathrm{NaCl}$ at $400 \mathrm{mOsm} / \mathrm{kg}$.

increased as shown by a 6-fold rise of $\left(\Delta \mathrm{H}_{2} \mathrm{O}\right.$ per osmotic gradient) in the jejunum and a $50 \%$ rise in the ileum. In the jejunum, $A D H$ caused a reversal in the direction of net sodium transfer from absorption to entry into the lumen. In the ileum the rate of sodium gain in the lumen was significantly increased. By contrast, the rate at which urea disappeared from the study segment was not altered during $\mathrm{ADH}$ administration. The net change in osmotically active solutes within the study segment, $\Delta \mathrm{mOsm}$, was calculated from the PEG concentration and from the osmolality of the proximal and distal aspirates. The expected values of $\Delta \mathrm{mOsm}$ were obtained by addition of the measured transfer rates of $\mathrm{Na}, \mathrm{K}$, urea, and D-mannitol, if we assume $\mathrm{Na}$ and $\mathrm{K}$ movement to be accompanied by univalent anions (see Tables IV and V). The expected and observed rates for $\Delta \mathrm{mOsm}$ were almost identical. This finding tends to confirm the validity of the reported transfer rates of individual solutes.

Comparison of the magnitude of the ADH-induced increase in water and sodium entry into the intestinal lumen, $\left(\frac{\text { change in } \Delta \mathrm{Na}}{\text { change in } \Delta \mathrm{H}_{2} \mathrm{O}} \cdot 1000\right)$, shows that the $\mathrm{ADH}$ effect during urea perfusions may be described as increased entry (or decreased loss) of a solution containing 142 and $126 \mathrm{mEq} /$ liter of sodium salts in jejunum and ileum, respectively.

Hypertonic urea and D-mannitol perfusions: effect of endogenous $A D H$. Hypertonic D-mannitol and urea perfusions in the hydrated and dehydrated state were carried out in the jejunum of four subjects. The number of observations is too small for statistical analysis, but the changes induced by dehydration during urea perfusions 
TABLE V

Effect of i.v. ADH (1 U/hr) on Ileal Water and Solute Transfer during Hypertonic Perfusions

\begin{tabular}{|c|c|c|c|c|c|c|}
\hline & \multicolumn{3}{|c|}{ Urea } & \multicolumn{3}{|c|}{ D-Mannitol } \\
\hline & No ADH & $\mathrm{ADH}$ & $P$ value & No ADH & $\mathrm{ADH}$ & $P$ value \\
\hline$\Delta \mathrm{H}_{2} \mathrm{O}, \mathrm{ml} / \mathrm{hr}$ per $\mathrm{cm}$ & $-4.72 \pm 0.43$ & $-7.37 \pm 0.68$ & $<0.01$ & $-7.64 \pm 0.88$ & $-8.02 \pm 0.97$ & $>0.1$ \\
\hline $\begin{array}{l}\text { Osmotic gradient, } \\
m O s m / k g^{*}\end{array}$ & $219 \pm 17$ & $242 \pm 19$ & $>0.05$ & $220 \pm 13$ & $238 \pm 18$ & $>0.1$ \\
\hline $\begin{array}{l}\Delta \mathrm{H}_{2} \mathrm{O} \text { per osmotic } \\
\text { gradient }\end{array}$ & $0.022 \pm 0.002$ & $0.033 \pm 0.004$ & $<0.02$ & $0.038 \pm 0.007$ & $0.040 \pm 0.010$ & $>0.1$ \\
\hline$\Delta \mathrm{Na}$, mmoles $/ \mathrm{hr}$ per $\mathrm{cm}$ & $-0.03 \pm 0.07$ & $-0.36 \pm 0.10$ & $<0.01$ & $-0.41 \pm 0.08$ & $-0.48 \pm 0.11$ & $>0.1$ \\
\hline$\Delta \mathrm{K}$, mmoles $/ \mathrm{hr}$ per $\mathrm{cm}$ & $-0.018 \pm 0.005$ & $-0.031 \pm 0.008$ & $>0.1$ & $-0.031 \pm 0.012$ & $-0.030 \pm 0.006$ & $>0.2$ \\
\hline $\begin{array}{l}\text { Mean Na concn, } \\
m E q / \text { liter }\end{array}$ & $111 \pm 2$ & $117 \pm 2$ & $>0.2$ & $109 \pm 2$ & $112 \pm 2$ & $>0.2$ \\
\hline $\begin{array}{l}\Delta \text { Urea or mannitol, } \\
\text { mmoles } / \mathrm{hr} \text { per } \mathrm{cm}\end{array}$ & $+1.15 \pm 0.29$ & $+1.09 \pm 0.29$ & $>0.2$ & $+0.021 \pm 0.027 \ddagger$ & $+0.021 \pm 0.032 \ddagger$ & $>0.2$ \\
\hline $\begin{array}{l}\text { Mean urea concn, } \\
\text { mmole/liter }\end{array}$ & $297 \pm 23$ & $291 \pm 26$ & $>0.2$ & - & 一 & - \\
\hline $\begin{array}{l}\text { Urine osmolality, } \\
\qquad m O s m / k g\end{array}$ & $67 \pm 7$ & $553 \pm 37$ & $<0.01$ & $107 \pm 10$ & $572 \pm 26$ & $<0.01$ \\
\hline$\Delta \mathrm{mOsm}, \mathrm{mOsm} / \mathrm{hr}$ per $\mathrm{cm}$ & $+1.15 \pm 0.43$ & $+0.24 \pm 0.25$ & $<0.02$ & $-0.74 \pm 0.24$ & $-0.94 \pm 0.30$ & $>0.2$ \\
\hline $\begin{array}{l}\text { Calculated } \Delta \text { mOsm } \S \\
m O s m / h r \text { per } \mathrm{cm}\end{array}$ & $+1.06 \pm 0.38$ & $+0.37 \pm 0.29$ & $<0.02$ & $-0.79 \pm 0.33$ & $-0.92 \pm 0.29$ & $>0.2$ \\
\hline
\end{tabular}

Data are derived from 13 subjects.

See legend of Table IV for explanation of abbreviations.

were of the same nature as those observed with exogenous $\mathrm{ADH}$ (Table VI). The slight increase in the rate of net sodium and water entry occurring during D-mannitol perfusions with exogenous $\mathrm{ADH}$ was not observed in these studies.

Effect of exogenous $A D H$ on small intestinal motility. Mean transit time of isotonic saline through a $30 \mathrm{~cm}$ segment of jejunum was calculated before and $60 \mathrm{~min}$ after the start of an i.v.
$\mathrm{ADH}$ infusion $(1 \mathrm{U} / \mathrm{hr})$ in six hydrated subjects. The transit time did not change; it was $13.4 \pm$ $1.6 \mathrm{~min}$ (mean $\pm 1 \mathrm{SE}$ ) before and $14.0 \pm 1.3 \mathrm{~min}$ during $\mathrm{ADH}$ administration $(P>0.2)$.

The response of jejunal motor activity to rapid i.v. injection of $\mathrm{ADH}$ was determined by balloon kymography in a total of nine hydrated subjects. All nine subjects received $1 \mathrm{U}$, and none showed a change in the kymograph recordings. Increased

TABLE VI

Jejunal Water and Solute Transfer during Hypertonic Perfusion in the Hydrated and Dehydrated State

\begin{tabular}{|c|c|c|c|c|}
\hline \multirow{4}{*}{$\begin{array}{l}\Delta \mathrm{H}_{2} \mathrm{O}, \mathrm{ml} / \mathrm{hr} \text { per } \mathrm{cm} \\
\text { Osmotic gradient, } m \mathrm{~m} O \mathrm{sm} / \mathrm{kg}^{*}\end{array}$} & \multicolumn{2}{|c|}{ Urea } & \multicolumn{2}{|c|}{ D-Mannitol } \\
\hline & \multirow{3}{*}{$\begin{array}{c}\text { Hydrated } \\
-1.64 \\
97\end{array}$} & Dehydrated & \multirow{3}{*}{$\begin{array}{c}\text { Hydrated } \\
-11.64 \\
83\end{array}$} & Dehydrated \\
\hline & & $-4.00 \quad(4 / 4) \ddagger$ & & $-10.33(2 / 4) \ddagger$ \\
\hline & & $80 \quad(2 / 4)$ & & $107 \quad(3 / 4)$ \\
\hline$\Delta \mathrm{H}_{2} \mathrm{O}$ per osmotic gradient & 0.013 & $0.076(4 /) 4$ & 0.151 & $0.098(3 / 4)$ \\
\hline$\Delta \mathrm{Na}$, mmoles $/$ hr per $\mathrm{cm}$ & -0.03 & $-0.50(4 / 4)$ & -0.66 & $-0.65 \quad(2 / 4)$ \\
\hline Mean Na concn, $m E q /$ liter & 110 & $114 \quad(2 / 4)$ & 94 & $99 \quad(3 / 4)$ \\
\hline Urine osmolality, $\mathrm{mOsm} / \mathrm{kg}$ & 77 & $(4 / 4)$ & 113 & $(4 / 4)$ \\
\hline
\end{tabular}

Data are'derived from four subjects.

See legend of Table IV for explanation of abbreviations.

Statistical evaluation is precluded by small sample size.

$\ddagger$ Number of times when individual differences between "hydrated" and "dehydrated" results were in the same direction as the change in mean values. 


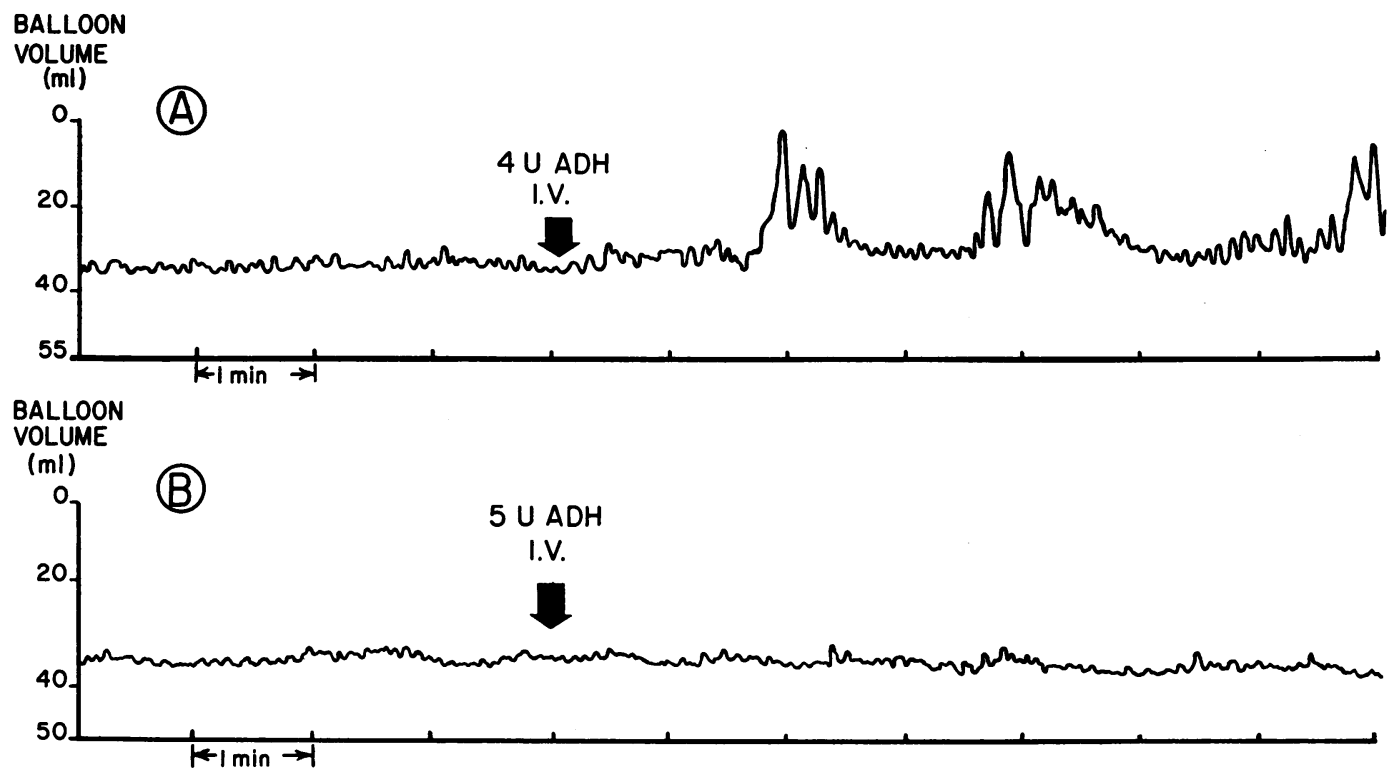

FIGURE 4 Balloon kymographic tracings from jejunum. Decreasing volume of air in balloon indicates intestinal contraction. $A$, positive response to i.v. injection of $3 \mathrm{U}$ of $\mathrm{ADH}$ (Pitressin). Preinjection: phasic waves of low amplitude; postinjection: appearance of larger, more protracted and complex contractions with rise in base line of recording. $B$, negative response to i.v. injection of $5 \mathrm{U}$ of $\mathrm{ADH}$ in another subject.

motor activity during the $10 \mathrm{~min}$ after injection was recorded in none of five subjects after $2 \mathrm{U}$, in one of seven subjects after $3 \mathrm{U}$, in two of three subjects after $4 \mathrm{U}$, and in three of five subjects receiving $5 \mathrm{U}$ of $\mathrm{ADH}$. Examples of no change and of increase in motor activity after ADH injection are shown on Fig. 4. In the studies on the effect of constant i.v. ADH infusion at $1 \mathrm{U} / \mathrm{hr}$ there was no statistically significant difference for any of the four measurements of motility between study and control subjects during both the $0-30$ min and the $50-150$ min period of recording. Simple visual inspection of the tracings also did not suggest any alteration in jejunal motor activity during $\mathrm{ADH}$ infusion. It appears, therefore, that the dose of $\mathrm{ADH}$ used during the intestinal perfusion studies $(1 \mathrm{U} / \mathrm{hr})$ is insufficient to cause detectable alterations in the motor activity of the intact human small intestine.

\section{DISCUSSION}

We have shown that the i.v. administration of small quantities of $\mathrm{ADH}$ regularly affects the transfer of water and sodium from the lumen of the small intestine during isotonic saline perfusions : absorption is either diminished or net gain of water and sodium occurs. The small amount of dextrose present in the test solution has no influence on the rate of water and sodium absorption from the study segment (9). The same ADH effect was observed when dehydration had resulted in endogenous release of $\mathrm{ADH}$. This effect appears to rule out the possibility that the $\mathrm{ADH}$-induced changes in salt and water absorption were mediated by alterations in extracellular water space or in the electrolyte and total solute concentration of serum. In contrast to the dehydrated state, $\mathrm{ADH}$ given intravenously to hydrated subjects tended to maintain a state of overhydration with a progressive fall in serum osmolality. The clearance of $\mathrm{ADH}$ from the human circulation is independent of plasma concentration, and the $t_{1}$ is in the range of 10-20 min; in chronically overhydrated subjects the $t_{2}$ is increased to about $40 \mathrm{~min}$ (18). The disappearance of the $\mathrm{ADH}$ effect on urine osmolality and on intestinal absorption within 60-90 min after termination of the ADH infusion (Fig. 3) allows, therefore, the conclusion that the $\mathrm{ADH}$ plasma concentration present in our subjects during infusion of $1 \mathrm{U} / \mathrm{hr}$ was not greatly in excess of the threshold concentration necessary for the antidiuretic effect to appear. 
ADH caused no change in the rates of dextrose and D-xylose absorption. It appears likely that the active transport mechanism for both sugars are saturated at much lower substrate concentrations than those present during our studies (Table III), and that the sugar absorption rates observed represented, therefore, largely sugar diffusion. Net transfer rates of water and sodium during dextrose and $\mathrm{D}$-xylose perfusions were unchanged by $\mathrm{ADH}$. In view of the large transmucosal concentration gradients for sodium, anions, and sugars present during these studies, the contribution of individual forces such as diffusion, solvent drag, and active transport to the observed net sodium and water transfer rates cannot be estimated. These data, therefore, are not necessarily in contradiction to the observed effect of $\mathrm{ADH}$ on sodium and water transfer from isotonic saline.

There exist several mechanisms by which $\mathrm{ADH}$ may have caused the observed changes in water and sodium transfer rates during normal saline perfusions. (a) Increased intestinal motility will lead to decreased contact time between test solution and the mucosal surface of the study segment. Although the commercial ADH preparation employed contains small amounts of oxytocic material, we demonstrated that the i.v. infusion of $1 \mathrm{U} / \mathrm{hr}$ of $\mathrm{ADH}$ changes neither the transit time through the study segment during perfusion nor the balloon kymographic recording of intestinal motility, and that injection of at least $3 \mathrm{U}$ is necessary to evoke a jejunal motor response. (b) Decreased mucosal blood flow. ADH (Pitressin) causes generalized arteriolar constriction and, consequently, a reduction in splanchnic blood flow (19). No information exists on the threshold dose of $\mathrm{ADH}$ required to decrease splanchnic blood flow in man; in the dog it appears to be greater than $50 \mathrm{mU} / \mathrm{kg}$ by single i.v. injection (20). This finding suggests that $\mathrm{ADH}$ did not cause a reduction in total intestinal blood flow during our studies. Jacobson, Swan, and Grossman (21) have shown that the secretory activity of the gastric mucosa is directly related to mucosal blood flow, and that the latter may vary independently from total gastric blood flow. Since the magnitude of the effective mucosal blood flow (EMBF) may become rate limiting for the net and unidirectional transfer of small molecules (22), the possibility exists that the small amounts of ADH employed effected a redistribution of intestinal blood flow with a decrease in EMBF. However, some observations argue against this possibility. First, ADH did not change the rates of water and sodium flux and of monosaccharide diffusion between blood and intestinal contents. Second, the rapid rates of water entry into the study segment during hypertonic mannitol perfusions, with and without i.v. $\mathrm{ADH}$, do not suggest that $\mathrm{ADH}$ had caused a decrease in EMBF. (c) $\mathrm{ADH}$-stimulated secretion of an isotonic solution of monovalent sodium salts. This mechanism would explain the occasionally observed net gain of water and sodium during saline perfusion and the changes occurring during hypertonic urea perfusions. Several observations argue against this hypothesis, however. First, there was no change in water and sodium transfer rates during isotonic sugar perfusions. Second, no increase in the flow rate of FIC could be demonstrated, whereas it has been shown (23) that 10or $15-\mathrm{cm}$ mixing segments allow for adequate mixing between test solution and FIC entering the mixing segment at flow rates up to $15 \mathrm{ml} / \mathrm{min}$. Since the relative contributions of intestinal gastric, pancreatic, and biliary secretions to FIC are not known, the possibility cannot be denied, however, that $\mathrm{ADH}$ administration had caused an increase in intestinal secretions with a corresponding decrease in the secretions of other organs. Third, the direction of change in unidirectional flux rates suggests that $\mathrm{ADH}$ acted by reducing the total movement of water and sodium from intestinal lumen to extracellular space without affecting the movement in the opposite direction. (d) $\mathrm{ADH}$ may interfere with the function of the active sodium transport mechanism ("pump"). Since water and sodium were present in equal concentrations on both sides of the mucosa, the $\mathrm{ADH}$-induced reduction in $\phi_{\mathrm{MS}}$ with constant $\phi_{\mathrm{SM}}$ are consistent with the view that the passive permeability of the mucosa to sodium and water is not altered by $\mathrm{ADH}$ (24). This finding suggests a totally different $\mathrm{ADH}$ effect than that postulated for the toad bladder in which $\mathrm{ADH}$-stimulated water and sodium absorption is believed to be due to increased availability of sodium ions to the "pump," as manifested by a rise in bidirectional $\phi^{\mathrm{Na}}(25)$. The net water and sodium secretion occurring during $\mathrm{ADH}$ infusion in some of the studies shown in Figs. 2 and 3 can be explained 
by assuming that water and salt are continuously secreted into the intestine, and that this process becomes apparent only in those studies where water and sodium absorption are more completely suppressed than in others.

While the mechanism by which $\mathrm{ADH}$ caused changes in water and electrolyte transfer during hypertonic perfusions cannot be clearly stated, these observations allow some comment on the use of the ratio $\left(\Delta \mathrm{H}_{2} \mathrm{O}\right.$ per osmotic gradient), obtained during hypertonic perfusions with several solutes, for calculation of equivalent mucosal pore size (10).

The test solution within the study segment had a higher total solute content but lower sodium concentration than serum. The resulting effective osmotic gradient between blood and intestinal lumen depends on the permeability of the intestinal mucosa for the various solutes present on either side of the membrane. In our studies, the effective osmotic pressure of only one solute is known, that of D-mannitol, to which the mucosa is impermeable. The actual effective osmotic gradient present provided a force for bulk water flow into the study segment, carrying with it electrolytes, mainly sodium salts, by the solvent drag effect (26). Simultaneously, sodium diffusion from blood to lumen occurred along the existing sodium concentration gradient. Additional processes that may have contributed to net sodium and water movement are active absorption of sodium from the lumen, carrying with it an obligatory amount of water, and secretion of water and sodium salts. It is commonly assumed that urea diffusion and bulk water flow share a common pathway through the mucosal cell (10). In this case the absence of a change in urea absorption during $\mathrm{ADH}$ infusion despite unchanged mean urea concentration in the study segment suggests that mucosal resistance to bulk water flow was unaffected by $\mathrm{ADH}$. A further argument against the possibility that $\mathrm{ADH}$ caused an increase in the rate of bulk water flow is the fact that the apparent sodium concentration in the additional fluid entering the sudy segment during $\mathrm{ADH}$ administration was approximately equal to that in serum. Alternate explanations for the $\mathrm{ADH}$-induced large increase in the flow of water and sodium into the study segment during urea perfusions are suppression of active sodium transport, stimulation of intestinal water and salt secre- tion, or a combination of changes in bulk flow, sodium transport, and secretion. The minor or absent effects of $\mathrm{ADH}$ on sodium movement during D-mannitol perfusions are difficult to reconcile with any of these concepts. The considerably higher rate of sodium gain in the lumen during D-mannitol compared to urea perfusions in the absence of $\mathrm{ADH}$ suggests, however, that D-mannitol itself, in the concentrations present, may have affected in some manner the mucosal transfer of sodium (11). Further study is necessary to establish this particular point.

In any event, the finding of a large $\mathrm{ADH}$ mediated increase in the rate of water entry into the study segment without change in $\Delta$ urea casts some doubt on the validity of attribuing the $\Delta \mathrm{H}_{2} \mathrm{O}$ observed during hyperonic urea perfusions solely to water bulk flow and on the use of these data for the calculation of effective or equivalent pore radii of the intestinal mucosa (10).

Levitan and Mauer (7) have demonstrated $\mathrm{ADH}$-induced reduction in water and sodium absorption from the human colon during perfusion with isotonic saline. The dose used was $1 \mathrm{U} / \mathrm{hr}$ i.v., but the authors were unable to show the reversibility of this effect. Interestingly, the action of $\mathrm{ADH}$ on the small intestine of other species is opposite to that on the human intestine: water absorption from isotonic saline increases after injection of $0.01 \mathrm{U} / \mathrm{kg}$ of $\mathrm{ADH}$ in the dog (4) and after $0.05 \mathrm{U} / \mathrm{kg}$ of $\mathrm{ADH}$ are administered to the rat (5). Sodium absorption rates were not measured in these studies. Results of the addition of $\mathrm{ADH}$ to the serosal medium of in vitro gut and colon preparations have been variable $(6,8)$.

Inspection of our Table I and of Levitan and Mauer's data (7) shows that during isotonic saline perfusion $\mathrm{ADH}$ essentially abolishes sodium and water absorption in the human jejunum, decreases it in the ileum and to a lesser degree in the colon. If water and salt absorption under natural conditions is similarly affected by $\mathrm{ADH}$, then it appears likely that a dehydrated subject will absorb orally ingested salt solution more slowly and in more distal parts of the gastrointestinal tract then when he is in the hydrated state.

\section{ACKNOWLEDGMENTS}

This investigation was supported by U. S. Public Health Service Grants RO1-AM-08251 and RO1-AM-09929 from 
the National Institute of Arthritis and Metabolic Diseases and by grant 5-MO1-FR-00058 from the Division of Research Grants, U. S. Public Health Service. Dr. Soergel is a recipient of the U. S. Public Health Service Research Career Development Award 5 K3-AM-16,605. Dr. Harris is recipient of the Postdoctoral Fellowship Award 4F2AM-22,638 from the U. S. Public Health Service, National Institute of Arthritis and Metabolic Diseases.

\section{REFERENCES}

1. Leaf, A. 1967. Membrane effects of antidiuretic hormone. Am. J. Med. 42: 745 .

2. Goodman, L. S., and A. Gilman. 1955. The Pharmacological Basis of Therapeutics. The MacMillan Company, New York. 2nd edition. 873.

3. Sawyer, W. H. 1967. Evolution of antidiuretic hormones and their functions. Am. J. Med. 42: 678 .

4. Blickenstaff, D. D. 1954. Increase in intestinal absorption of water from isosmotic saline following pitressin administration. Am. J. Physiol. 179: 471.

5. Dombrádi, G. A., F. Krizsa, and T. Jancsó. 1960. Die Kinetik der intestinalen Wasserresorption der Ratte unter dem Einfluss von ADH. Acta Physiol. Acad. Sci. Hung. 17: 301.

6. Aulsebrook, K. A. 1961. Effect of vasopressin on sodium transfer by rat colon in vitro. Endocrinology. 68: 1063.

7. Levitan, R., and I. Mauer. 1966. The influence of pitressin administration on salt and water absorption from the human colon. Clin Res. 14: 301. (Abstr.)

8. Green, K., and A. J. Matty. 1966. Effects of vasopressin on ion transport across intestinal epithelia. Life Sci. 5 : 205.

9. Whalen, G. E., J. A. Harris, J. E. Geenen, and K. H. Soergel. 1966. Sodium and water absorption from the human small intestine. The accuracy of the perfusion method. Gastroenterology. 51: 975.

10. Fordtran, J. S., F. C. Rector, Jr., M. F. Ewton, N. Soter, and J. Kinney. 1965. Permeability characteristics of the human small intestine. J. Clin. Invest. 44: 1935.

11. Soergel, K. H., G. E. Whalen, and J. A. Harris. 1968. The passive movement of water and sodium across the human small intestinal mucosa. J. Appl. Physiol. 24: 40.
12. Roe, J. H., and E. W. Rice. 1948. Photometric method for the determination of free pentoses in animal tissues. J. Biol. Chem. 173: 507.

13. Sanderson, P. H. 1952. Potentiometric determination of chloride in biological fluids. Biochem. J. 52: 502.

14. Annino, J. S. 1964. Nitrogen. Clinical Chemistry. Principles and Procedures. Little, Brown and Company, Boston, Mass. 3rd edition. 144.

15. Wilcoxon, F., and R. A. Wilcox. 1964. Some rapid approximate statistical procedures. Lederle Laboratories, Div. of American Cyanamid Co., Pearl River, N. Y.

16. Dillard, R. L., H. Eastman, and J. S. Fordtran. 1965. Volume-flow relationship during the transport of fluid through the human small intestine. Gastroenterology. 49: 58.

17. Bingham, J. R., F. J. Ingelfinger, and R. H. Smithwick. 1950. The effects of sympathectomy on the motility of the human gastrointestinal and biliary tracts. Gastroenterology. 15: 6.

18. Lauson, H. D. 1967. Metabolism of antidiuretic hormones. Am. J. Med. 42 : 713.

19. Texter, E. C., Jr. 1963. Small intestinal blood flow. Am. J. Digest. Diseases. 8: 587.

20. Schapiro, H., E. H. Storer, and L. G. Britt. 1966. Action of antidiuretic hormone on gastric secretion. Arch. Surg. 92: 699.

21. Jacobson, E. D., K. G. Swan, and M. I. Grossman. 1967. Blood flow and secretion in the stomach. Gastroenterology. 52: 414.

22. Winne, D., and H. Ochsenfahrt. 1967. Die formale Kinetik der Resorption unter Berücksichtigung der Darmdurchblutung. J. Theoret. Biol. 14: 293.

23. Cooper, H., R. Levitan, J. S. Fordtran, and F. J. Ingelfinger. 1966. A method for studying absorption of water and solute from the human small intestine. Gastroenterology. 50: 1.

24. Curran, P. F., and A. K. Solomon. 1957. Ion and water fluxes in the ileum of rats. J. Gen. Physiol. 41: 143.

25. Lichtenstein, N. S., and A. Leaf. 1966. Evidence for a double series permeability barrier at the mucosal surface of the toad bladder. Ann. N.Y.Acad. Sci. $137: 556$.

26. Fordtran, J. S., and J. M. Dietschy. 1966. Water and electrolyte movement in the intestine. Gastroenterology. $50: 263$. 